\title{
Outsourcing salespeople in building arousal towards retail buying
}

Received (in revised form): 3rd April, 2008

\section{Rajagopal}

is Professor of Marketing at Monterrey Institute of Technology and Higher Education (ITESM), Mexico City Campus and a fellow of the Royal Society for Encouragement of Arts, Manufacture and Commerce, London. His biography is listed in the Who's Who in the World, 2008. He holds doctoral degree from Ravishankar University, India and has been conferred the National Researcher - Level-II of Mexican National System of Researchers. He teaches various topics of marketing in graduate, doctoral executive development programmes at the Institute. Dr Rajagopal has held key positions in many premier management institutes in India including Administrative Staff College of India.

Keywords outsourcing, sales promotion, consumer behaviour, retailing, inter-personal communications, consumer marketing

Abstract The strategy of outsourcing salespeople (sales promoters) to prospect for customers through inter-personal communication and develop pre-purchase arousal for products and services is being increasingly employed by manufacturing and marketing firms. Sales promoters are deployed at strategic locations such as in front of malls, large self-service stores, departmental stores and traffic islands in the city. This paper attempts to analyse behavioural drivers that influence consumers' leisure shopping behaviour and measure customer value through empirical investigation in Mexico. The study reveals that sales promoters significantly stimulate interest among customers towards buying products and trigger shopping arousal. Consumers are influenced in making buying decisions by the product attractiveness and pre-purchase arousal generated by the sales promoters.

Journal of Database Marketing \& Customer Strategy Management (2008) 15, 106-118. ;doi:10.1057/dbm.2008.3; published online 12 May 2008

Rajagopal

Department of Marketing

Business Division,

Monterrey Institute of

Technology and Higher Education, ITESM

Mexico City Campus 222, Calle del Puente,

Tlalpan DF 14380, Mexico Tel: +52 5554832251 ;

Fax: +52 555483 1341; e-mail: rajagopal@itesm.mx, prof_rajagopal@yahoo.com; Homepage: http://www. geocities.com/prof_ rajagopal/homepage.html

\section{INTRODUCTION}

Customer-centred companies are increasingly engaged in outsourcing salespeople to enhance the market coverage and augment volume of sales in the competitive business environment. By outsourcing salespeople commonly known as promoters to perform certain activities targeted toward customers, firms are engaging in service networks. Outsourced salespeople are engaged in disseminating brand image of the company and bringing more customers in the business fold by delivering satisfaction and caring their buying intentions. They are deployed by companies and distributors at strategic locations such as in front of malls, large selfservice stores, departmental stores and traffic islands in the city. Services provided by the sales promoters directly for the customer are likely to play an important role in building a firm's brand image and equity. ${ }^{1}$

Many firms have discovered that outsourcing sales promotion activities can 
also backfire dramatically and put reputations at risk if promoters mismanage the process. Yet, despite the apparent risks, managers in a widening range of industries are exploring the scope of sales outsourcing. This strategy of promoting sales has helped many companies to cut costs on advertising and publicity, and sharpen their focus on core competencies. ${ }^{2}$ Personal shopping motives, values and perceived shopping alternatives are often considered independent inputs into a choice model. It is argued that shopping motives influence the perception of retail store attributes as well as the attitude towards the retail stores themselves. ${ }^{3}$ In the process of making buying decisions in leisure shopping, purchase acceleration and product trial are found to be the two most influential variables.

Firms and their distributors outsource salespeople intending to influence customer behaviour and buying decision process in such a way that higher sales targets are achieved. Sales systems can be classified as a behaviour-based sales system (BBSS) and an outcome-based control system (OBSS), which explain the selling process in a market. ${ }^{4}$ A BBSS aims at the selling process inducing buyers at the pre-purchase stage, and helps retailers to sell higher volumes in view of the customer pull effect generated by the salespeople. On the contrary, OBCS evaluates the sales force in light of end results, and compensation is usually incentive-based. In view of the growing competition among firms however, the OBCS is widely used together with the BBCS in a continuum between the two sales systems. ${ }^{5}$ Growing use of the BBCS is driven by such economic principles as Agency theory. The Agency theory envisages the sales manager as having predetermined guidelines for outsourced salespeople to act on his behalf and accordingly the firms objectives are affected by the outsourced salespeople or sales promoters. ${ }^{6}$
This paper attempts to analyse behavioural drivers that influence consumers' leisure shopping behaviour and measure customers' value through empirical investigation in Mexico. The role of outsourced salespeople who act as sales promoters for stimulating arousal and satisfaction as behavioural drivers, which influence the buying behaviour of consumers and measures the extent of satisfaction, has been analysed. Customer prospecting strategies of sales promoters in swaying leisure shopping and driving brand loyalty are also discussed in the paper.

\section{PREVIOUS CONTRIBUTIONS}

\section{Developing buying arousal}

Arousal in shopping makes consumers stay longer in the stores, purchase product and make buying decisions. Perceptions of shopping duration, emotional levels and merchandise evaluations are derived from the level of arousal experienced by the consumers while interacting with the sales promoters. ${ }^{7}$ Five essential qualities of aesthetic judgment that include interest, subjectivity, exclusivity, thoughtfulness and internality need to be nurtured among consumers to develop conviction in buying. The quality of aesthetic judgment driven by in-store aura and arousal towards new products, exercised by the customers in association with the sales promoters, will determine the extent to which new products and brands promoted enhances quality of life. ${ }^{8}$ The three distinct dimensions of emotions, which include pleasantness, arousal and dominance, have been identified as major drivers in regard to consumer buying decisions. Convergence of sales promotion, customer's perceptions, value for money and product features drive arousal among customers. ${ }^{7}$

There are some common strategies adopted by retailers to overcome the problems of fickle consumers, price-slashing competitors and mood swings in the 
economy. Such wishful thinking holds that sales promoters will thrive if only they communicate better with consumers during pre-purchase situations and assist in product demonstrations involving consumers to help their purchase decisions. ${ }^{9}$ The negotiations with sales promoters, whether pleasant or unpleasant, moderate the arousal effect on satisfaction and the buying behaviour of customers.

\section{Role of outsourced salespeople}

Relationship advancement through sales promoters in a firm has a positive significant impact on the growth of sales and developing customer value. Outsourced salespeople identify appropriate customers from different markets, facilitate the dialogue with the firm and bring customers together with the firm to process the sales. Sales promoters support interactive learning processes and bridge the gap between the customers and the firm. ${ }^{10}$ The bargaining power of firms increases with outsourced salespeople who stimulate the demand for products and contribute to the enhanced sales at retail outlets. It has been observed that pull effect for the brands supported by the sales promoters increases at the retail stores as customers gather the pre-buying information from sales promoters. ${ }^{11}$ Sales promoters offer samples and giveaways of many consumer products during leisure shopping, which catalyse consumer buying behaviour towards these products. Many types of promotions were measured in a study within seven food categories including sweet biscuits, snack foods, confectionery, chips/savoury snacks, cereals, dairy snacks and ice cream. Foods that utilised promotional tactics were categorised as either healthy or unhealthy, according to set criteria. Giveaways accounted for 13 per cent of all promotions and were commonly used in conjunction with another promotional method by the sales promoters who are outsourced by the manufacturing firm. ${ }^{12}$
Firms that introduce new products frequently or emerge as less familiar brands in the marketplace engage in pushing sales by working with customers and outsourced salespeople. A broad set of process standards makes it easy to determine the selling strategies for the outsourced teams in a given market. Such standards help firms evaluate the costs vs the benefits of outsourcing. Eventually these costs and benefits will be visible to buyers in terms of satisfaction and will develop demand-pull effects. ${ }^{13}$ Firms must consider and alter four factors over time: the differing roles that internal salespeople and external selling partners should play, the size of the sales force, its degree of specialisation and the way salespeople apportion their efforts among different customers, products and activities. These variables are critical because they determine how quickly sales forces respond to market opportunities, influence salespersons' performance and affect companies' revenues, costs and profitability. ${ }^{14}$

A new strategy among the multinational companies engaged in competition of identical products like carbonated drinks and purified bottled water has emerged, which can be explained by two-dimensional framework in reference to distributors' capability levels (low, medium and high) and outsourcing sales force to enhance market coverage. A match between distributor capability levels and outsourcing sales force needs is posited to be the key to a sustainable relationship between suppliers and their customers. ${ }^{15}$ Some researchers, however, have found that the relationship between customers and outsourced salespeople may not be sustainable in the long run. There is a common set of key contractual elements that exist in most outsourcing contracts. The nature of customer-promoter relationship functions as the key in the selling process for new products. In this process the perceptional problems with customers can greatly 
devalue the customer-promoter relationship and the brand as a whole. ${ }^{16}$

\section{Driving prospective buyers}

A recent strategy of retailers is the promotion of consumer arousal and enjoyment as a major influencing factor in making buying decisions. These factors reveal personalised enjoyment during shopping. Arousal during shopping may be seeded through multifaceted activity that may be performed in various ways and embody different consumer feelings. It is also argued that outsourced salespeople need to focus more on the consumers engaged in leisure shopping. ${ }^{17}$ It has been observed in some studies that consumers who intend to shop on short notice, generally lean towards impulsive or compulsive buying behaviour driven by arousal effect in the retail stores. Gender, age, a leaning towards unplanned purchases and a tendency to buy products not on shopping lists, serve to predict compulsive tendencies. ${ }^{18}$ At times, however, sales promoters fail to recognise that what influences buyers' satisfaction is not the same as what engenders store loyalty and consequently do not effectively develop the cognitive drive to stimulate buying decisions. Hence, they need to vigilantly manage the quality of arousal by developing adequate customer involvement in the buying process. ${ }^{19}$

Customer values are created towards the new products through individual perceptions, and organisational and relational competence. ${ }^{20}$ Firms need to ascertain a continuous organisational learning process with respect to the value creation chain and measure performance of the new products introduced in the market. In the growing competitive markets, the large and reputed firms are developing strategies to move into the provision of innovative combinations of products and services as 'high-value integrated solutions' tailored to each customer's needs. This is seen as being more effective than simply 'moving downstream' into services. ${ }^{21}$ The product attractiveness may comprise various product features including improved attributes, use of advanced technology, innovativeness, extended product applications, brand augmentation, perceived use value, competitive advantages, corporate image, product advertisements, sales and services policies associated therewith. These features contribute to building sustainable customer values in regard to making buying decisions about the new products. ${ }^{22}$ The attractiveness of new products is one of the key factors affecting the decision making of customers and in turn is related to market growth and sales. The higher the positive reactions of the customers towards the new products in view of their attractiveness, the higher the growth in sales.

It has been observed in some studies that consumers, who intend to shop on short notice, generally lean towards impulsive or compulsive buying behaviour. A consumer's compulsive buying is an important area of inquiry in consumer behaviour research. The importance of studying compulsive buying stems, in part, from its nature as a negative aspect of consumer behaviour. ${ }^{17}$ Practically, consumers react favourably to leisure sales campaigns of goods and services. Customer value, however, plays a decisive role in the shopping process. It may be argued that individual consumer behaviour towards a buying option is a function of preference for the option; whether it is considered an option or a choice constraint is personally directed. The consumer response is also affected by the cost of search associated with making a decision on leisure shopping in reference to innovative products and campaigns. $^{23}$

There is an increasing importance in building behavioural thrust among the potential buyers through effective communication and sales induction at customers' convenience. This process of building buyer behaviour is largely managed 
by the outsourced salespeople with a focus on nine underlying factors of varying characters important to customer satisfaction. These are awareness, selection, persuasion, convenience, trial, attention, location, promotional activities and merchandising policy. ${ }^{24}$ Sales promoters instill emotions in customers in terms of merchandise choice, visual merchandising, store environment, sales personnel attitude, pricing policies and promotional activities during the prepurchase stage. These factors are the very foundation of consumer satisfaction and are decision drivers when buying products. ${ }^{25}$

\section{STUDY DESIGN}

\section{Framework of hypothesis}

Consumption among consumers has often been dichotomised in terms of its arousalhedonic nature and has been closely associated with the level of satisfaction leading to determination of the customer value. ${ }^{26}$ As new and exciting products are introduced, firms prospect the consumers through inter-personal negotiations managed by the sales promoters and inculcate high arousal among customers towards buying these products. Do-ityourself (DIY) and computer-aided simulations act as stimuli to consumers who tend to exhibit a positive response. Further, it is predicted that the magnitude of such a positive response will be proportional to the value of an option in making buying decisions at the available price. ${ }^{23}$ Accordingly, the hypothesis may be framed as:

H1: Consumers are influenced in making buying decisions by the product attractiveness and pre-purchase arousal generated by the sales promoters during leisure shopping.

Visual effects associated with products often stimulate buying decisions among young consumers. Point of sales brochures, catalogues and posters build assumptions about the perceived use value and motivational relevance of buying decisions in regard to product. Emotional visuals exhibited on contextual factors such as proximity or stimulus size, drive perception and subjective reactions on utility and expected satisfaction of the products. ${ }^{27}$ A pleasant negotiation ambience with sales promoters where music, hands-on experience facilities and recreation are integrated helps in maximising consumer arousal towards buying. It has been observed that consumers perceive positive effects during interaction with sales promoters if arousal is high. ${ }^{28}$ Hence, it may be hypothesised that:

H2: Consumers also develop higher brand loyalty during pre-purchase interaction with the sales promoters, which boosts arousal and conformity towards buying decisions.

The impact of the initial interaction of customers with the sales promoters can be measured in reference to the degree of stimulation and pleasure gained by customers. Interactive tools on product learning provided by the sales promoters significantly affect the level of arousal and pleasure that contributes towards experience and thereby influence the buying behaviour. As higher stimulation or interactive learning provided by the sales promoters focuses on gaining initial experience on the product use, consumers tend to engage in further arousing activities by acquiring the product. ${ }^{29}$ In view of such consumer arousal-led behaviour in retail buying, the hypothesis may be delineated as

H3: Product information and experience offered to the customers during leisure shopping increase randomness of variety-seeking behaviour.

Difficulty in buying decisions, however, increases during leisure shopping and can 
overrule brand loyalty, which may pose a threat to customer satisfaction in the long run. Sometimes a negative response to the leisure time sale is expected, independent of any short-run price advantages at the retail outlets. ${ }^{30}$ Hence, the hypothesis may be derived as

H4: Consumers are attracted by innovative sales techniques and gain higher instore arousal but they sometimes feel lower satisfaction during postpurchase usage.

The magnitude of consumer response to clearance sales is weighed in two ways evaluative and behavioural. First, consumer satisfaction with the decision process leading to the expected level of satisfaction is measured, which may be expressed as one of a number of cognitive and affective responses. The satisfaction is the customer's perception of the value received in a transaction or relationship and it helps in making re-patronage decisions on the basis of their predictions concerning the value of a future product. Hence, many retailers develop innovative approaches to prospect new customers for new products by strengthening customer relationship and value management strategies. ${ }^{31}$

\section{Sample size}

In order to measure the effectiveness of the outsourced salespeople in stimulating buying decisions of customers during shopping, a preliminary investigation has been conducted in 11 retail self-service stores in Mexico City including four departmental stores and two self-service stores on construction material spread over three retail locations. September-December has been identified as the leisure period when companies and distributors engage maximum outsourced salespeople in Mexico, which contribute to 18-22 per cent of regular salespeople of the firm. The data were collected on 31 variables closely related to influencing the customer values. These variables include various perspectives of customer satisfaction and sales strategies for the new products in order to increase retail sales. The data sets were categorised in reference to pre-purchase and point of purchase variables for the study as illustrated in Table 1.

Data have been collected from 210 outsourced salespeople engaged in selling products for various companies. The products handled by the outsourced salespeople have been categorised into the areas of processed food products, toiletries and personal hygiene. The respondents belonged to Kraft (cheese), DANONE (frozen milk food), Cadbury's (chocolates), Nestlé (ice cream), Kellogg (energy bar) and Unilever (Knorr processed food) companies among the processed food products category. Salespeople from S C Johnson (cleaning liquids), Colgate Palmolive (toilet soaps) and Procter and Gamble (detergent) were engaged in promoting toiletries while respondents were promoting personal hygiene products of Kimberly Clark (Kotex sanitary towels), Procter and Gamble (skin care) and BDF (Nivea face wash). Accordingly, questionnaires were administered to 70 respondents in each category of industry. Filled-in responses were carefully examined and 22 responses of 28 samples were eliminated from the study due to inconsistency and paucity of information. Hence, information from 182 respondents was considered for data processing and analysing the results. It has been found that the overall response rate in the survey was 86.66 per cent. The descriptive statistics of the data sets for the variable segments used in the analysis of the study is exhibited in Table 2.

Initially, focus group discussion of a representative sample from selected companies was carried out to understand their role in prospecting customers. Based on the pre-purchase promotion activities carried out by outsourced salespeople, major 
Table 1: Variables chosen for the study

\begin{tabular}{|c|c|c|c|c|}
\hline \multicolumn{3}{|c|}{ Pre-purchase variables } & \multicolumn{2}{|c|}{ Point of purchase variables } \\
\hline Product based & Innovation related & Arousal and merriment & Comparative & Retailer based \\
\hline$v S_{1}(7)$ & $v S_{2}(4)$ & $V S_{3}(8)$ & $v S_{4}(7)$ & $V S_{5}(5)$ \\
\hline $\begin{array}{l}\text { Appearance } \\
\text { Sensory } \\
\text { Durability } \\
\text { Newness } \\
\text { Health oriented } \\
\text { Need } \\
\text { Fun }\end{array}$ & $\begin{array}{l}\text { Organic } \\
\text { New ingredients } \\
\text { Process technology } \\
\text { Value-based }\end{array}$ & $\begin{array}{l}\text { Initial awareness } \\
\text { Product features } \\
\text { Advertising } \\
\text { Hands-on experience } \\
\text { Take-home trials } \\
\text { Social status } \\
\text { Referrals } \\
\text { Satisfaction }\end{array}$ & $\begin{array}{l}\text { Value for money } \\
\text { Price sensitivity } \\
\text { Buying cost } \\
\text { Guarantee } \\
\text { Cross promotion } \\
\text { Value additions } \\
\text { Competitiveness }\end{array}$ & $\begin{array}{l}\text { Display } \\
\text { Retailer support } \\
\text { Availability } \\
\text { In-store promotion } \\
\text { Responsiveness }\end{array}$ \\
\hline
\end{tabular}

VS=Variable segment.

Figures in parentheses indicate number of variables.

Table 2: Descriptive statistics for the selected variable groups for the study

\begin{tabular}{lccrrr}
\hline Variable groups & $\boldsymbol{V S}_{\mathbf{1}} \mathbf{( 7 )}$ & $\boldsymbol{V S}_{\mathbf{2}} \mathbf{( 4 )}$ & $\boldsymbol{V S}_{\mathbf{3}} \mathbf{( 8 )}$ & $\boldsymbol{V S}_{\mathbf{4}} \mathbf{( 7 )}$ & $\boldsymbol{V S}_{\mathbf{5}}(\mathbf{5})$ \\
\hline Sample size & 182 & 182 & 182 & 182 & 182 \\
Mean & 6.720 & 4.288 & 5.761 & 4.503 & 6.065 \\
Standard deviation & 1.030 & 0.735 & 0.810 & 0.879 & 1.226 \\
Standard error & 0.054 & 0.038 & 0.042 & 0.046 & 0.064 \\
Skewness & -0.906 & -1.085 & -1.050 & -0.610 & -0.463 \\
Sample variance & 1.061 & 0.540 & 0.656 & 0.773 & 1.504 \\
\hline
\end{tabular}

VS=Variable segment.

Figures in parentheses indicate number of variables.

variable segments were identified keeping in view the objectives of the study.

Accordingly, pre-coded questionnaires were developed for the study and administered to the respondents. Besides questions with precoded options, some open-ended questions were also administered separately for qualitative assessment of the responses. The content analysis was done to summarise the open-ended questions using software QSR NVivo2. This software has powerful tools for combining subtle coding with qualitative linking, shaping and modelling of qualitative information. The analysis of qualitative responses has largely succeeded in deriving appropriate managerial implications of the study. The questionnaires were initially drafted in English and later translated into Spanish for use in Mexico. The questionnaires have been translated from English to Spanish using the literal translation and transposition techniques. In translating some questions, the technique of equivalence or reformulation has been used to give a correct sense to the sentence.

\section{RESULTS AND DISCUSSIONS}

During the pre-purchase period arousal tends to increase retail sales of processed food products, toiletries and personal hygiene products by about 3.27 per cent per person upon interacting with sales promoters. Sales promoters operate in strategic locations such as in front of malls, large self-service stores, departmental stores and traffic islands. The implied difference between the pre-purchase arousal-led shopping and regular shopping is an average of 16.24 per cent additional spending over regular spending average. It has been observed that the longer the consumers are attracted by the sales promoters, product promotions, innovation and technology and DIY experience, the more spendthrift they 
Table 3: Regression analysis of the arousal effect and time spread in buying products $n=182$

\begin{tabular}{llll}
\hline Arousal indicators/product category & Processed food & Toiletries & Personal hygiene \\
\hline Interaction with sales promoters & 0.5296 & $0.6419^{\star *}$ & $0.7204^{\star}$ \\
& $(0.8881)$ & $(1.1620)$ & $(0.9294)$ \\
Pre-purchase stimulus & 0.6120 & $0.8621^{\star}$ & $0.7329^{\star *}$ \\
& $(0.3296)$ & $(0.4725)$ & $(0.3904)$ \\
Product promotion & $0.7738^{\star}$ & $0.6381^{\star *}$ & $0.5579^{\star *}$ \\
DIY experience & $(0.0324)$ & $(0.1281)$ & $(0.1082)$ \\
& $0.3774^{\star}$ & $0.8199^{\star}$ & $0.6003^{\star *}$ \\
Take-home trial & $(0.3321)$ & $(1.1409)$ & $(0.7444)$ \\
& $0.9411^{\star *}$ & $0.8637^{*}$ & 0.7146 \\
Referral influence & $(1.2104)$ & $(0.1280)$ & $(1.3621)$ \\
& 0.5238 & $0.9314^{\star}$ & $0.8624^{\star}$ \\
Post-purchase recreation by sales promoters & $(1.3170)$ & $(0.1455)$ & $(0.1992)$ \\
& $(0.7460)$ & 0.5986 & 0.5311 \\
\end{tabular}

$p$-values * $>0.01$ and ${ }^{* *}>0.001$.

In the above table coefficients represent the marginal effects on the average time spread during the leisure shopping per capita.

Each cell represents separate regression.

Figures presented in parentheses indicate standard errors.

become. The categorical expenditure on shopping influenced by the in-store arousal in the referred to period as observed during the study is exhibited in Table 3.

It may be seen from Table 3 that buying decisions influenced by pre-purchase stimulus influences 86.21 per cent of customers towards buying toiletries suggested by the sales promoters while take home trials offered by the sales promoters induce 94.11 per cent customers towards buying the processed food. Many customers, however, derive satisfaction from postpurchase recreation or fun provided by the sales promoters and customers perceive value addition to their decision to buy the products suggested by the sales promoters. The results exhibited in the Table 3 show that 59.86 per cent of customers derive satisfaction from the post-purchase recreation and fun activities associated with the buying of toiletries prospected by the sales promoters. Customers, however, derived a lower level of satisfaction from the post-purchase activities conducted by the sales promoters of processed food and personal hygiene products. In addition, the results reveal that per capita sales tend to increase in all product categories, although marginal in case of personal hygiene products as compared to other products, during the leisure shopping season. Sales during the leisure season are stimulated by the sales promoters through personal interactions, take-home trials, hands-on experiences to customers and post-purchase recreations, which are perceived by the customers as economic and relational advantages to products, brands and services of the companies. Accordingly, the results discussed in the Table 3 are consistent with hypothesis $\mathrm{H}_{1}$.

It may be observed from Table 4 that significant values of the change factor representing the perceived advantages in reference to appropriate product positioning strategies associated with the quality, pricing and communication would help driving positive customer influence during the prepurchase stage. Effective interactions with the sales promoters, strong product differentiation revealing uniqueness, value for money and stimulating product trial response help in building brand value among customers during the pre-purchase decision process.

The level of satisfaction derived by the customers during the pre-purchase stage 
Table 4: Sensitivity analysis for the variables affecting pre-purchase decisions $n=182$

\begin{tabular}{|c|c|c|c|c|c|c|c|}
\hline $\begin{array}{l}\text { Change } \\
\text { factor }\end{array}$ & $\begin{array}{l}\text { Perceptional } \\
\text { change } \\
\text { parameters }\end{array}$ & $\begin{array}{l}\text { Value estimation } \\
\text { parameters for } \\
\text { sales promoters }\end{array}$ & $\begin{array}{l}\text { Location-1 } \\
\text { (three retail } \\
\text { stores) }\end{array}$ & $\begin{array}{l}\text { Location-2 } \\
\text { (four retail } \\
\text { stores) }\end{array}$ & $\begin{array}{l}\text { Location-3 } \\
\text { (four retail } \\
\text { stores) }\end{array}$ & $p$ & $\begin{array}{l}\text { Chi- } \\
\text { square }\end{array}$ \\
\hline$C_{1}$ & $\begin{array}{l}\text { Product } \\
\text { knowledge }\end{array}$ & $\begin{array}{l}\text { Customer } \\
\text { interactivity, } \\
\text { information } \\
\text { dissemination, } \\
\text { referrals }\end{array}$ & 0.836 & 0.821 & 0.921 & $0.598^{*}$ & 84.22 \\
\hline$C_{2}$ & Brand value & $\begin{array}{l}\text { Trial response, } \\
\text { product line of } \\
\text { company, value } \\
\text { for money, quality } \\
\text { and uniqueness }\end{array}$ & 0.913 & 0.869 & 0.626 & $0.491^{*}$ & 87.26 \\
\hline$C_{3}$ & $\begin{array}{l}\text { Price } \\
\text { sensitivity }\end{array}$ & $\begin{array}{l}\text { Competitive } \\
\text { advantage, } \\
\text { affordability, } \\
\text { repeat buying }\end{array}$ & 0.942 & 0.824 & 0.511 & $0.366^{\star \star}$ & 64.02 \\
\hline
\end{tabular}

$p$-values ${ }^{*}<0.05$ and ${ }^{* *}<0.01$.

through interactions with the sales promoters at retail stores may be seen as a significant change factor $\left(C_{2}\right)$, which largely keeps the brand value of products high at the retail stores in locations 1 and 2 as compared to retailers in location 3. It may also be seen from the result exhibited in the Table through the change factor $\left(C_{1}\right)$ that inter-personal communication, information spread and referrals significantly influence pre-purchase decisions of customers in all the retail store locations except in location 3. This may be due to the lower level of involvement of the customers with the sales promoters in these retail stores. The results presented in Table 4, however, are consistent with hypothesis $\mathrm{H}_{2}$.

The results of the correlation matrices indicate that there exists a higher degree of correlation between the variety of products and perceived brand difference $\left(V_{1}, V_{2}\right)$, innovativeness in the products and perceived brand difference $\left(V_{3}, V_{2}\right)$, and product varieties and perceived use values $\left(V_{1}, V_{3}\right)$. Similarly, the variables pertaining to takehome trial experiences and perceptions on repeat buying $\left(V_{4}, V_{6}\right)$, recreational value and influence of referrals $\left(V_{5}, V_{7}\right)$ are also observed to have a correlation of a higher degree. The correlations among these variables are exhibited in Table 5 .

It may be observed from the above matrix that the coefficient has a maximum value of 0.915 , which showed significant concern for multicolinearity between the variables - innovativeness in the product offered by the sales promoters and influence of referrals $\left(V_{3}, V_{7}\right)$. It has been observed during the study that initial consumption of the innovative products introduced by the sales promoters at strategic shopping locations enhances shopping arousal of the customers. Attractive in-store ambience further escalates the shopping arousal of customer and their level of satisfaction remains high. The long-term customer value, however, is influenced by both the price and nonprice factors associated with the product. Performances of the company in retail management of the product in terms of just-in-time supplies, display, point of sales approaches and customer services, however, also help in building the customer values for the product in a given market. Therefore, the results exhibited in Table 4 are consistent with hypothesis $\mathrm{H}_{3}$.

It has been observed during the study that consumers experienced shopping 
Table 5: Inter-group ${ }^{a}$ correlation matrices $(n=182)$

\begin{tabular}{|c|c|c|c|c|c|c|c|}
\hline Variable segments & $v_{1}$ & $V_{2}$ & $V_{3}$ & $V_{4}$ & $v_{5}$ & $v_{6}$ & $v_{7}$ \\
\hline $\begin{array}{l}\text { Variety products with value } \\
\text { additions }\left(V_{1}\right)\end{array}$ & 1.000 & & & & & & \\
\hline Perceived brand difference $\left(V_{2}\right)$ & $0.829^{*}$ & 1.000 & & & & & \\
\hline $\begin{array}{l}\text { Innovativeness and perceived use } \\
\text { value }\left(V_{3}\right)\end{array}$ & 0.671 & $0.694^{*}$ & 1.000 & & & & \\
\hline $\begin{array}{l}\text { Customer satisfaction on take- } \\
\text { home trials }\left(V_{4}\right)\end{array}$ & $0.827^{*}$ & 0.510 & $0.735^{\star}$ & 1.000 & & & \\
\hline $\begin{array}{l}\text { Recreational value during post } \\
\text { purchase }\left(V_{5}\right)\end{array}$ & 0.251 & 0.294 & 0.306 & $0.682^{*}$ & 1.000 & & \\
\hline Brand value and repeat buying $\left(V_{6}\right)$ & $0.542^{\star *}$ & $0.791^{*}$ & $0.728^{*}$ & $0.843^{*}$ & 0.475 & 1.000 & \\
\hline Influence of referrals $\left(V_{7}\right)$ & $0.573^{\star *}$ & 0.451 & $0.915^{\star}$ & $0.868^{*}$ & $0.822^{*}$ & $0.819^{*}$ & 1.000 \\
\hline
\end{tabular}

$p$-values * $>0.01$ and ${ }^{* *}>0.001$.

ariable segments are formed from the variable groups chosen for the study as exhibited in Table 1.

arousal at two different stages of buying process. The pre-purchase arousal was felt by the consumers through product advertisements, inter-personal communications and product simulations provided by the sales promoters. The postpurchase arousal has been experienced by the consumers as an extended benefit associated with purchase of the product. Table 6 exhibits the results of shopping arousal experienced by the consumers in a phased manner during their leisure time.

The $\beta$ coefficients, derived through linear regression model in Table 6 show that prepurchase arousal (0.745) significantly influences the buying decision for toiletries while the post-purchase arousal (0.732) induces the decision making for hygiene products. The point of sales stimulation (0.893) and in-store ambience (0.921) also influence significantly the decision of consumers towards buying innovative personal hygiene products. The postpurchase stimuli, however, have been found lower for the toiletries (0.345) and processed food products $(0.472)$, as consumers did not find any amusement or challenging activities organised by the sales promoters. Still all factors influencing shopping arousal contribute towards augmenting the sales of products during leisure shopping. Hence, the results presented in the Table 6 are consistent with hypothesis $\mathrm{H}_{4}$.

\section{MANAGERIAL IMPLICATIONS}

Systematically explored concepts in the field of customer value and market-driven approach towards new products would be beneficial for a company to derive longterm profit optimisation strategy over the period. On a tactical level, managers need to consider the optimum spread of customers on a matrix of product attractiveness and market coverage. A company may also need to consider emphasising an integrated promotion strategy for new brands in reference to attributes, awareness, trial, availability and repeat (AATAR) principle. One of the challenges for the manager of a retail store is to enhance the in-store ambience to influence the young consumers to prolong their stay in the store in order to shop and explore the zone of experience for new products. An augmented and sustainable customer value builds loyalty towards the product and the brand. Systematically explored customer preferences and arousaldriven retailing approach towards new products would be beneficial for a company to derive long-term profit optimisation strategy over the period. This needs careful attention and the application of managerial 
Table 6: Measure of shopping arousal and buying intensity among young consumers $(n=182)$

\begin{tabular}{|c|c|c|c|c|c|c|c|c|}
\hline $\begin{array}{l}\text { Product } \\
\text { categories }\end{array}$ & \multicolumn{4}{|c|}{$\beta$ coefficients } & \multicolumn{3}{|c|}{ Arousal-led sales (in US \$) } & $\begin{array}{l}\Delta \% \text { in leisure } \\
\text { as compare } \\
\text { to nonleisure } \\
\text { sales }\end{array}$ \\
\hline Toiletries & $0.745^{\star}$ & 0.345 & $0.872^{\star}$ & $0.781^{*}$ & 85.10 & 68.46 & 16.64 & 24.30 \\
\hline $\begin{array}{l}\text { Personal } \\
\text { hygiene }\end{array}$ & $0.685^{\star \star}$ & $0.732^{*}$ & $0.893^{*}$ & $0.921^{*}$ & 80.94 & 62.60 & 18.34 & 29.41 \\
\hline
\end{tabular}

$p$-values ${ }^{*}>0.01$ and ${ }^{* *}>0.001$.

Sales promoters contribute significantly towards effectively prospecting customers and increasing sales

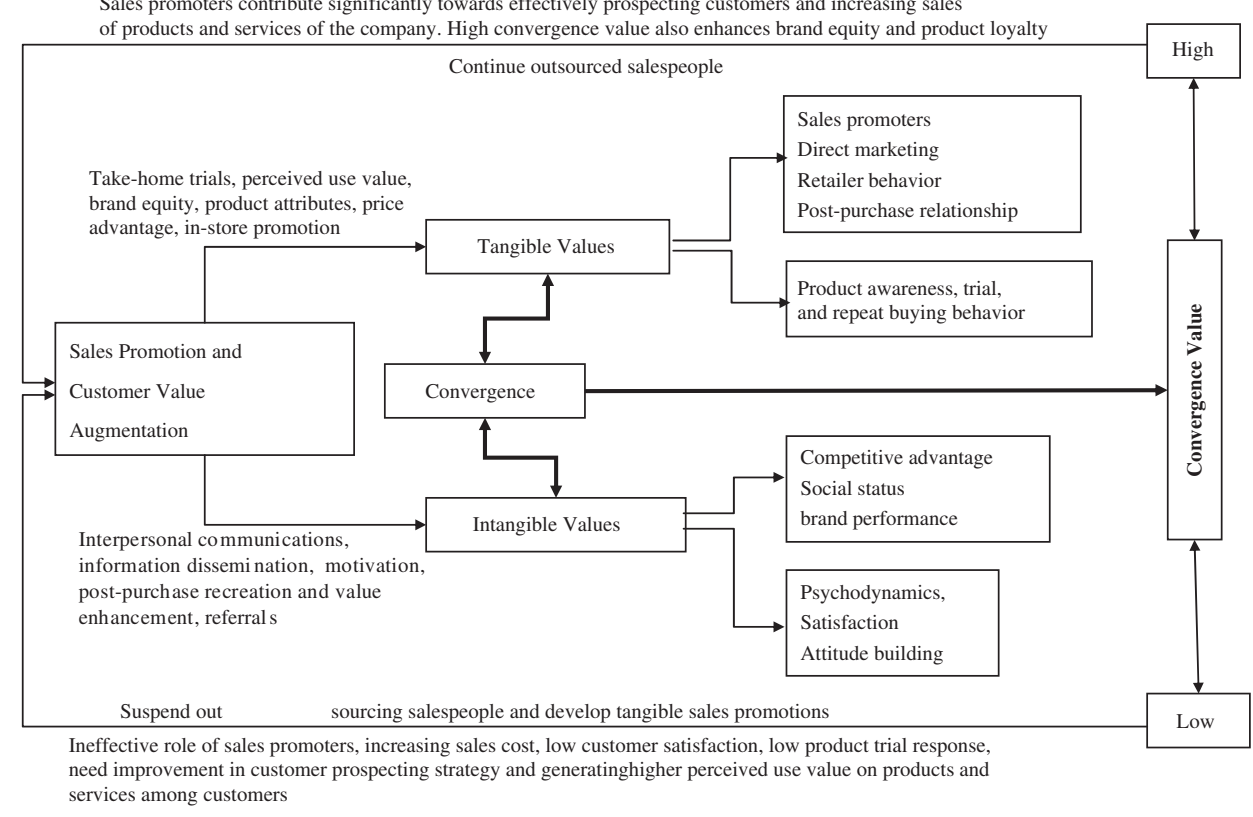

Figure 1: Sales promotions and buying decision process

judgment and experience to generate consumer arousal and develop appropriate sales strategies for stimulating the buying decision.

Appropriate promotional strategies considering the economic and relational variables discussed in the study may be developed by the managers upon measuring the intensity of leisure shopping and the scope of expanding the tenure of leisure shopping in view of maximising consumer satisfaction and increasing the volume of sales. As customer satisfaction has become one of the principal measures of retail performance and leisure shopping behaviour towards buying innovative and fashion products, the retail promotion need to be oriented towards augmenting the customer values and in view of the various factors affecting shopping arousal of customers, a strategy paradigm for augmenting such effects is exhibited in Figure 1.

At the retail point of purchase, three factors, including consumer, value for money and product advantages, converge. Firms must make the most of the sales promotions available to customers to strengthen customer satisfaction, brand value, repeat buying behaviour and increase in the sales of products. By engaging in 
effective pre-purchase interaction with the customers, planning appropriate sales promotions and user-friendly packaging, generating adequate shopping arousal and focusing on in-store ambience, marketers can effectively serve the various interests of the manufacturer, the retailer and the customers. A strategic focus considering how customers and competitors will react to any promotional effort, as well as the message delivered and the stature in the marketplace of the brand being delivered should be developed by the firms in order to strengthen and streamline the prepurchase promotions in the marketplace. Hence, managers should not only tailor promotion programmes successfully to target customers, but also skillfully monitor implementation through customer culture and competition challenges.

\section{CONCLUSION}

Outsourcing salespeople as sales promoters is commonly practiced by multinational companies to conduct direct sales promotion activities with target customers to develop pre-purchase shopping arousal. The sales promoters are deployed by the companies and distributors at strategic locations such as in front of malls, large selfservice stores, departmental stores and traffic islands in the city. The paper discusses major factors affecting shopping decisions of customers in reference to interactive sales promotion approaches, shopping behaviour, brand value, perceived values and price. The discussion in the study reveals that sales promoters significantly stimulate interest among customers towards buying products and trigger shopping arousal. Consumers are influenced in making buying decisions by the product attractiveness and pre-purchase arousal generated by the sales promoters during leisure shopping. Sales promoters disseminate product information through inter-personal communications, brochures, referral videos and virtual resources to potential customers to develop conviction towards buying. It has been observed in the study that customers develop brand value and repeat buying behaviour through hands-on experience of product, innovative sales techniques and by gaining higher instore arousal during shopping. The framework for measuring the customer values discussed in this paper provides analytical dimensions for establishing the customer relationship by the firm and to optimise its profit levels by gaining the competitive advantage in the short run.

\section{LIMITATIONS OF THE STUDY}

Like many other empirical studies, this research might also have some limitations in reference to sampling, data collection and generalisation of the findings. The samples drawn for the study may not be enough to generalise the study results. The questionnaires were translated in Spanish for the respondents in Mexico, which might have conveyed varied conceptual sense to some extent. The open-ended questions were answered by the Mexican respondents in Spanish and at times transcription of the audio may have overlooked some issues. The study does not indicate how behaviour control, price differentiation and promotion design efficiency cause changes in the consequences leading to leisure shopping behaviour among the customers. To ensure that the data cover wider spatial and temporal dimensions in the study region, data should be cleansed and filtered with many variability factors affecting consumer behaviour and retailer performance.

\section{Acknowledgments}

I acknowledge the support provided by Amritanshu Rajagopal, student of Industrial and Systems Engineering of ITESM, Mexico City Campus, in data collection, translation of questionnaires into Spanish, computing the data and developing tables in this study.

\section{References}

1 Morgan, F., Deeter-Schmelz, D. and Moberg, C. R. (2007) 'Branding implications of partner firm-focal firm relationships in business-to-business service 
networks', Journal of Business and Industrial Marketing, Vol. 22, No. 6, pp. 372-382.

2 Johnson, L. K. (2006) 'Successful business process outsourcing', Sloan Management Review, Vol. 47, No. 2, pp. 5-6.

3 Morschett, D., Swoboda, B. and Foscht, T. (2005) 'Perception of store attributes and overall attitude towards grocery retailers: The role of shopping motives', The International Review of Retail, Distribution and Consumer Research, Vol. 15, No. 4, pp. 423-447.

4 Anderson, E. and Oliver, R. L. (1987) 'Perspective on behavior-based versus outcome-based sales force control systems', Journal of Marketing, Vol. 51, No. 4, pp. 76-88.

5 Krafft, M. (1999) 'An empirical investigation of the antecedents of sales force control systems', Journal of Marketing, Vol. 63, No. 3, pp. 120-134.

6 Wright, P., Mukherji, A. and Kroll, M. J. (2001) 'A re-examination of agency theory assumptions: Extensions and explorations', Journal of SocioEconomics, Vol. 30, No. 5, pp. 413-429.

7 Rajagopal (2007) 'Stimulating retail sales and upholding customer value', Journal of Retail and Leisure Property, Vol. 6, No. 2, pp. 117-135.

8 Dobson, J. (2007) 'Aesthetics as a foundation for business activity', Journal of Business Ethics, Vol. 72, No. 1, pp. 41-46.

9 Berry, L. L. (2001) 'The old pillars of new retailing', Harvard Business Review, Vol. 79, No. 4, pp. 131-137.

10 Walter, A. and Gemünden, H. G. (2000) 'Bridging the gap between suppliers and customers through relationship promoters: Theoretical considerations and empirical results', Journal of Business and Industrial Marketing, Vol. 15, No. 2, pp. 86-105.

11 Gómez, M. I., Maratou, L. M. and Just, D. R. (2007) 'Factors affecting the allocation of trade promotions in the U.S. food distribution system', Review of Agricultural Economics, Vol. 29, No. 1, pp. 119-140.

12 Chapman, K., Nicholas, P., Banovic, D. and Subramaniam, R. (2006) 'The extent and nature of food promotion directed to children in Australian supermarkets', Health Promotion International, Vol. 21, No. 4, pp. 331-339.

13 Davenport, T. H. (2005) 'The coming commoditization of processes', Harvard Business Review, Vol. 83, No. 6, pp. 100-108.

14 Zoltners, A. A., Sinha, P. and Lorimer, S. E. (2006) 'Match your sales force structure to your business life cycle', Harvard Business Review, Vol. 84, No. 7-8, pp. 80-89.

15 Kim, K. I., Syamil, A. and Bhatt, B. J. (2007) 'A resource-based theory of supplier strategy', International Journal of Logistics Systems and Management, Vol. 3, No. 1, pp. 20-33.

16 Platz, L. A. and Temponi, C. (2007) 'Defining the most desirable outsourcing contract between customer and vendor', Management Decision, Vol. 45, No. 10 , pp. 1656-1666.

17 Bäckström, K. (2006) 'Understanding recreational shopping', The International Review of Retail,
Distribution and Consumer Research, Vol. 16, No. 2, pp. 143-158.

18 Shoham, A. and Brencic, M. M. (2003) 'Compulsive buying behavior', Journal of Consumer Marketing, Vol. 20, No. 2, pp. 127-138.

19 Miranda, M., Kónya, L. and Havrila, I. (2005) 'Shopper's satisfaction levels are not only the key to store loyalty', Marketing Intelligence and Planning, Vol. 23, No. 2, pp. 220-232.

20 Johanson, U., Mårtensson, M. and Skoog, M. (2001) 'Measuring to understand intangible performance drivers', European Accounting Review, Vol. 10, No. 3, pp. 407-437.

21 Davies, A. (2004) 'Moving base into high-value integrated solutions: A value stream approach', Industrial and Corporate Change, Vol. 13, No. 5, pp. 727-756.

22 Lafferty, B. A. and Goldsmith, R. E. (2004) 'How influential are corporate credibility and endorser attractiveness when innovators react to advertisement for a new high-technology product?', Corporate Reputation Review, Vol. 7, No. 1, pp. 24-26.

23 Rajagopal (2006) 'Leisure shopping behavior and recreational retailing: A symbiotic analysis of marketplace strategy and consumer response', Journal of Hospitality and Leisure Marketing, Vol. 15, No. 2, pp. 5-31.

24 Anselmsson, J. (2006) 'Sources of customer satisfaction with shopping malls: A comprehensive study of different customer segments', The International Review of Retail, Distribution and Consumer Research, Vol. 16, No. 1, pp. 115-138.

25 Otieno, R., Harrow, C. and Lea-Greenwood, G. (2005) 'The unhappy shopper, a retail experience: Exploring fashion, fit and affordability', International Journal of Retail \& Distribution Management, Vol. 33, No. 4, pp. 298-309.

26 Wakefield, K. L. and Inman, J. J. (2003) 'Situational price sensitivity: The role of consumption occasion, social context and income', Journal of Retailing, Vol. 79, No. 4, pp. 199-212.

27 Codispoti, M. and De Cesarei, A. (2007) ' Arousal and attention: Picture size and emotional reactions', Psychophysiology, Vol. 44, No. 5, pp. 680-686.

28 Wirtz, J., Mattila, A. S. and Tan, R. L. P. (2007) 'The role of arousal congruency in influencing consumers' satisfaction evaluations and in-store behaviors', International Journal of Service Industry Management, Vol. 18, No. 1, pp. 6-24.

29 Menon, S. and Kahn, B. (2002) 'Cross-category effects of induced arousal and pleasure on the internet shopping experience', Journal of Retailing, Vol. 78, No. 1, pp. 31-40.

30 Shugan, S. M. (1980) 'The cost of thinking', Journal of Consumer Research, Vol. 7, No. 2, pp. 99-111.

31 Ganesh, J., Arnold, M. J. and Reynolds, K. E. (2000) 'Understanding the customer base of service providers: An examination of the differences between switchers and stayers', Journal of Marketing, Vol. 64, pp. 65-87. 